Research Article

\title{
Tensile Failure Mechanism of Antiseepage System for Slope with Solid Waste Underground Landfill
}

\author{
Liu Fei $\mathbb{D}^{1}$ and Zhongxi Jiang $\mathbb{D}^{2}$ \\ ${ }^{1}$ Anhui Province Coal Mine Exploration Engineering Technology Research Center, Suzhou University, Suzhou 234000, China \\ ${ }^{2}$ Shenzhen Research Institute, Shanghai Jiao Tong University, Shenzhen 518057, China \\ Correspondence should be addressed to Zhongxi Jiang; s11jzx@163.com
}

Received 10 September 2018; Accepted 30 October 2018; Published 5 December 2018

Guest Editor: Jian Sun

Copyright (c) 2018 Liu Fei and Zhongxi Jiang. This is an open access article distributed under the Creative Commons Attribution License, which permits unrestricted use, distribution, and reproduction in any medium, provided the original work is properly cited.

\begin{abstract}
The antiseepage membrane applied to the slope of solid waste landfill often shows tensile failure in projects, which results in ineffective antiseepage system and serious environmental pollution. In order to ensure the practical performance of the antiseepage membrane, the tensile force of it was studied, and the settlement mechanical model of the interaction between landfill body, antiseepage membrane, and cushion was established after comprehensively considering the effects of dead weight, lateral pressure, settlement, and foundation boundary. The analytical solutions of the tensile force and displacement of the antiseepage membrane was calculated through differential equation of equilibrium. With general slag and ardealite slag as the research objects, the major parameters affecting the internal tensile force of the antiseepage membrane were analyzed and studied by the combination of numerical and theoretical methods. The results show that the internal tensile force of the antiseepage membrane is greatly affected by the parameters such as the membrane-slag interface friction angle, the membrane-cushion interface friction angle, the buried depth, and the single step height. The theoretical slope normal stress and membrane pull-up force are basically consistent with the numerical calculation results, which indicates that the theory is universally applicable to tackle the tensile failure of the antiseepage membrane in the solid waste landfill system.
\end{abstract}

\section{Introduction}

Landfilling is widely used around the world as one of the major methods for treating solid waste. The amount of solid waste treated by landfilling in China accounts for more than $70 \%$ of the total treatment [1-4], and most solid waste contains toxic and hazardous substances, which may cause serious pollution to the environment [1, 5-7]. The antiseepage membrane is extensively used in the antiseepage system of solid waste landfills due to its advantages of sound leakproofness, flexibility, and corrosion resistance. It can effectively prevent pollutants from getting into the soil or groundwater, playing a significant role in environmental protection [8-13]. In the principle of saving cultivated land, protecting the environment, and reducing costs, China's landfills are mostly adapted to the local conditions and designed as valley-type [14]. In practical engineering, there will be friction between the upper and lower surfaces of the membrane and a tensile force inside the membrane $[15,16]$ due to impacts of temperature, stacking, and settlement. When the friction between the surfaces is imbalanced, it will transform into the internal tensile force. Excessive tensile force will tear the membrane and invalidate the antiseepage system consequently $[9,17,18]$. In the existing researches, the interface characteristics of geosynthetics in landfill antiseepage systems [19-21] have been tested frequently, but the interface friction characteristics were seldom analyzed. Due to the lack of reasonable and effective theoretical support for the mechanism of interaction between the landfill body, the antiseepage membrane, and the cushion, the design and construction usually rely on experiences. In order to theoretically explain the tearing of antiseepage membrane on the slope, Giroud and Beech [22], and Koerner and Hwu [23] calculated the tensile force of the 
geomembrane on the slope through the limit equilibrium method; Kodikara, Liu, Liu and Gilbert, and Liu and Gilbert [21, 24-26] investigated the evolution of the internal tensile force of slope membrane in refuse landfills. However, only the dead weight or the effect of the dead weight and lateral pressure on the membrane was considered in the above researches. The theoretical model was so simplified that the results were far from the practical reality, and it can hardly be applied to engineering practices. With only landfill body as the research subject, the results are not universally applicable.

According to the numerous experiments of Seo et al. [27], the shear-displacement relationship between geotechnical composites is closer to the ideal elastoplastic model, which is therefore used for analysis in this paper. Through theoretical and numerical methods, the effects of waste settlement and foundation platform on the stress born by the antiseepage membrane were also considered in this paper, in addition to the impact of solid waste dead weight and lateral pressure. The mechanical failure mechanism of the antiseepage membrane and the key factors resulting in the antiseepage membrane damage were taken as the focus, providing a theoretical basis for the antiseepage structure design used in the industrial solid waste landfill slope. It is of great significance to ensure the completeness of the antiseepage membrane, prevent pollutants leakage, and protect the environment.

\section{Mechanical Mechanism}

2.1. Mechanical Model. In the industrial solid waste landfill, the slag is usually in fine articles without any foreign object. Therefore, the antiseepage membrane is generally in direct contact with the slag and the membrane is protected by cushions underneath. The stress born by antiseepage membrane unit was analyzed according to the laying of antiseepage membrane on the landfill slope, and the simplified model is shown in Figure 1.

The landfill body on the membrane was taken for this study and the mechanical model is shown in Figure 2. The unit was simultaneously stressed by the landfill body's dead weight $\sigma_{\mathrm{v}}$, horizontal lateral pressure $\sigma_{\mathrm{h}}$, and the pull-down force $\sigma_{\mathrm{d}}$ caused by relative settlement, among which the $\sigma_{\mathrm{h}}$ is in proportion to the $\sigma_{\mathrm{v}}$.

The static equilibrium of the unit was also analyzed, getting the normal stress and shear stress on the antiseepage membrane as shown in Formula (1):

$$
\left.\begin{array}{l}
\sigma_{\mathrm{n}}=\left[\cos ^{2} \theta+K_{x}\left(\sin ^{2} \theta+\tan \varphi^{\prime} \frac{1}{2} \sin 2 \theta\right)\right] \gamma x \sin \theta, \\
\tau_{\mathrm{u}}=\left[\frac{1}{2}\left(1-K_{x}\right) \sin 2 \theta+K_{x} \tan \varphi^{\prime} \sin ^{2} \theta\right] \gamma x \sin \theta .
\end{array}\right\}
$$

When the maximum static friction on the membraneslag interface is insufficient to withstand the sliding force of the unit, relative slippage will occur between the landfill body and the antiseepage membrane. In this case, the pull- down force of the landfill body on the membrane should be the maximum static friction, and the value is smaller than the shear stress value calculated by the static equilibrium. Therefore, the practical friction angle $\varphi_{a}$ of the membrane-slag interface subjects to the smaller one of the static force calculation value and the slippage occurring value:

$$
\varphi_{\mathrm{a}}=\min \left\{\varphi_{\mathrm{u}}, \arctan \frac{\tau_{\mathrm{u}}}{\sigma_{\mathrm{n}}}\right\},
$$

where $\sigma_{\mathrm{n}}$ represents the normal stress on the membrane-slag interface; $\tau_{\mathrm{u}}$ is the shear stress on the membrane-slag interface; $\theta$ is the slope angle; $X$ represents the distance between the antiseepage membrane end and the anchored end ( $0 \leq x \leq L, L$ is the total length of the antiseepage membrane); $\gamma$ is the average unit weight of the landfill body $\left(\mathrm{kN} / \mathrm{m}^{3}\right) ; K_{x}$ is the lateral pressure coefficient taking the empirical formula $K_{x}=1-\sin \varphi^{\prime} ; \varphi^{\prime}$ is the internal friction angle of the landfill body; and $\varphi_{\mathrm{u}}$ is the ultimate friction angle of the membrane-slag interface.

Assuming that the friction angle of the membranecushion interface is constant, the shear stress between the membrane and the cushion can be expressed as

$$
\tau_{l}=\sigma_{\mathrm{n}} \cdot \tan \varphi_{\mathrm{p}}
$$

where $\tau_{l}$ represents the membrane-cushion interface shear stress and $\varphi_{\mathrm{p}}$ is the friction angle of the membrane-cushion interface.

The foundation boundary impact assumption was premised on the following: (1) there is no lateral displacement of the tailings at the pond bottom foundation or on the anchoring platform of the slope toe; (2) there is a tensile force in the membrane, which means that the slag will possibly slide on the cushion. When the slag shows a sliding relative to the cushion, the lower slag will support the upper somehow. If there is no relative sliding or deformation, there is no tensile stress in the membrane, and therefore, the upper slag can remain stable without the support from the lower part. Due to the settlement, the slag closer to the foundation bottom will show smaller displacement and is more vulnerable to the effect of the foundation. And the shear stress on the critical position of the pond foundation and the slope junction is not zero. Thus, when $\tau_{\mathrm{u}}>\tau_{l}$, the slope foundation impact factor $\eta(\eta=1-h x / 2 \mathrm{~h})$ was introduced.

$$
\frac{d T}{d x}=\left(\tau_{l}-\tau_{\mathrm{u}}\right)\left(1-\frac{x}{2 L}\right)
$$

where $T$ is the tensile force of the antiseepage membrane $h_{x}$ from the slag top.

2.2. Theoretical Analysis. Assuming that the antiseepage membrane unit is elastic, when the membrane-slag interface shear force exceeds the membrane-cushion interface shear strength $\left(\tau_{\mathrm{u}}>\tau_{l}\right)$, a tensile force is generated in the membrane, and the system differential equation of equilibrium is obtained: 


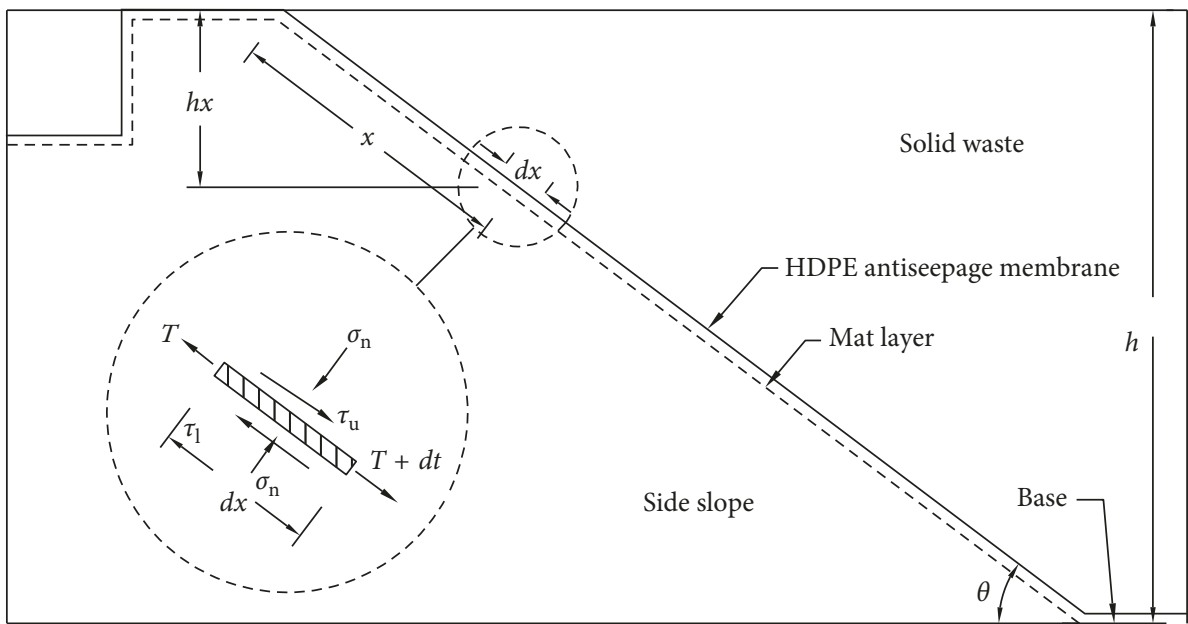

Figure 1: Schematic model of antiseepage membrane installed on industrial waste landfill slopes.

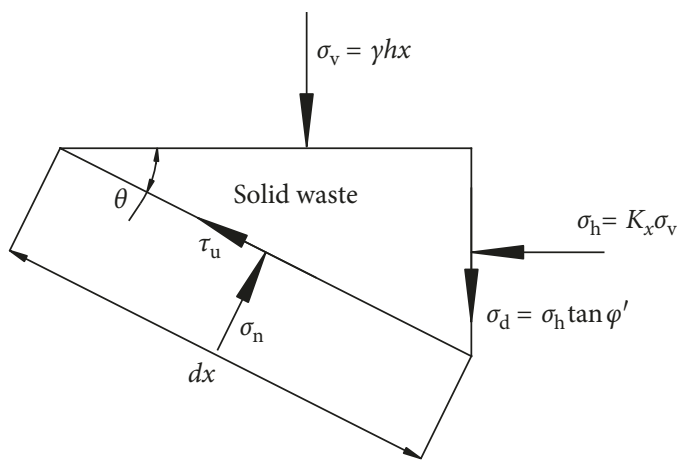

FIGURE 2: Force equilibrium analysis of a tailings element.

$$
\left.\begin{array}{l}
\frac{d T}{d x}=\left(\tau_{l}-\tau_{\mathrm{u}}\right)\left(1-\frac{x}{2 L}\right), \\
\frac{d u}{d x}=\frac{T}{t E},
\end{array}\right\}
$$

where $u$ is the displacement of the antiseepage membrane $h_{x}$ from the slag top; $E$ and $t$ represent Young's modulus and thickness of the antiseepage membrane, respectively.

The antiseepage membrane is anchored at the top, which means there is no top displacement, the foundation of the slope bottom is the platform, and the slag settlement is consistent. In this case, the tensile force in the membrane is 0 . The boundary conditions of Formula (5) were generated:

$$
\begin{aligned}
\left.u\right|_{x=0} & =0, \\
\left.\frac{d u}{d x}\right|_{x=L} & =0,
\end{aligned}
$$

where $\quad b=\left[\cos ^{2} \theta+K_{x}\left(\sin ^{2} \theta+\tan \varphi^{\prime} 1 / 2 \sin 2 \theta\right)\right] \gamma \sin \theta$, $c=b \cdot \tan \varphi_{\mathrm{a}}$, and $c^{\prime}=b \cdot \tan \varphi_{\mathrm{p}}$.

Formulas (1)-(6) were solved simultaneously:

$$
\begin{aligned}
& u=-\frac{\left(c^{\prime}-c\right)}{24 L t E} x^{4}+\frac{\left(c^{\prime}-c\right)}{6 t E} x^{3}+\frac{\left(c-c^{\prime}\right)}{3 t E} L^{2} x, \\
& T=-\frac{\left(c^{\prime}-c\right)}{6 L} x^{3}+\frac{\left(c^{\prime}-c\right)}{2} x^{2}+\frac{c-c^{\prime}}{3} L^{2} .
\end{aligned}
$$

It can be known from Formula (7) that when $x=0$, the tensile force $T$ has an extreme value; therefore,

$$
T_{\max }=\frac{c-c^{\prime}}{3} L^{2} \text {. }
$$

\section{Parameter Study}

In order to study the law of various parameters' influence on the tensile force of the antiseepage membrane, the antiseepage membrane was laid in a stepped manner in this research corresponding to the basic working conditions in general, with the top anchored and the single step height $h=$ $10 \mathrm{~m}$. One of the steps was taken as the object, and the other parameters were taken as $\gamma=15.3 \mathrm{kN} / \mathrm{m}^{3}, K_{x}=0.39$.

According to the experimental research, the friction angle $\varphi^{\prime}$ in the slag and the friction angle $\varphi_{\mathrm{u}}$ of the membrane-slag interface are basically in a relationship of $\varphi_{\mathrm{u}}=0.667 \varphi^{\prime}$; in addition, the internal friction angle $\varphi^{\prime}$ was assumed as $30^{\circ}, 35^{\circ}, 40^{\circ}$, and $45^{\circ}$ since the internal friction angle ranges from $30^{\circ}$ to $45^{\circ}$ depending on the moisture content and the degree of consolidation.

3.1. Friction Angle of the Membrane-Slag Interface. The relationship between the actual friction angle of the membrane-slag and the slope angle is shown in Figure 3. The actual friction angle of the membrane-slag interface increased with the slope angle, indicating an equal proportional relationship; when the actual friction angle reached the membrane-slag interface friction angle, it stopped increasing. When the membrane-slag interface friction angles were $20^{\circ}, 23.33^{\circ}, 26.67^{\circ}$, and $30^{\circ}$, the slope angles impacted by the full role of the actual friction angles 


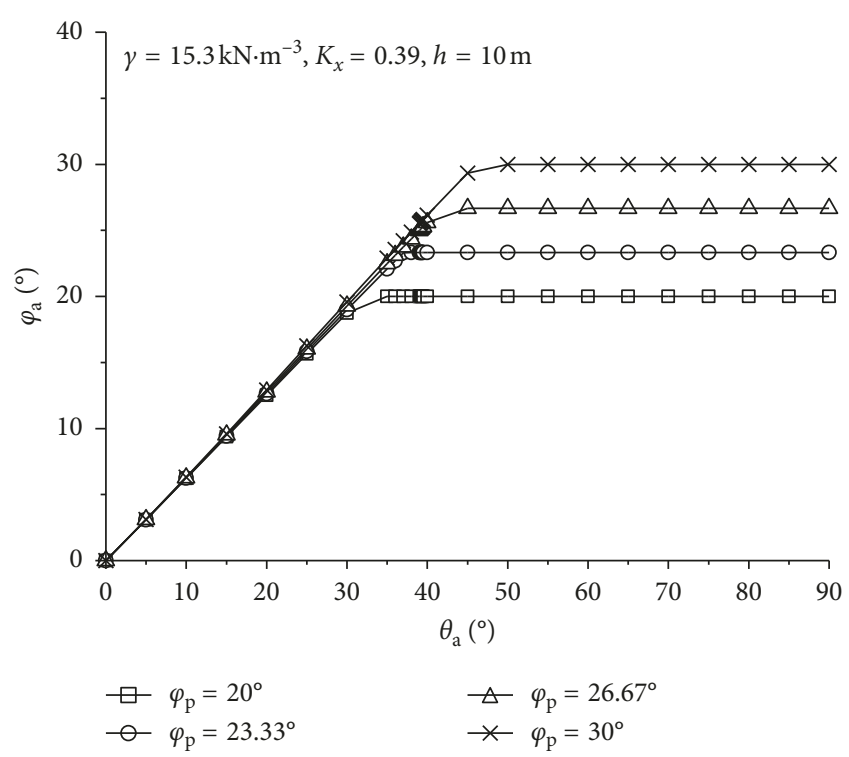

Figure 3: The relationship between the actual friction angle of the membrane-slag interface and the slope angle.

were $32^{\circ}, 37^{\circ}, 45^{\circ}$, and $47^{\circ}$, respectively. It was indicated that the slope angles corresponding to the ultimate friction angle of the membrane-slag interface increased with the growth of the friction angle of the membrane-slag interface, and this slope angle was called the ultimate slope angle $\theta_{T_{\max }}$.

\subsection{Ultimate Tensile Force of the Antiseepage Membrane.} As shown in Figure 4, the greater the ultimate friction angle of the membrane-slag interface, the bigger the ultimate tensile force on the membrane; if the friction angle of the membrane-slag interface was fixed, the value of the slope angle's tensile force was the greatest when the actual friction angle reached its extremum, which suggested that the pullup force on the membrane was the greatest at the ultimate slope angle.

\subsection{Ultimate Tensile Force of the Antiseepage Membrane.} Assume that the internal friction angle of the material is normally distributed, and take $\varphi^{\prime}=37.5^{\circ}$ and the other parameters as $\gamma=15.3 \mathrm{kN} / \mathrm{m}^{3}, K_{x}=0.39$, and $\varphi_{\mathrm{u}}=25^{\circ}$.

The change of the ultimate tensile force in the antiseepage membrane with the slope angle $\theta$ is shown in Figure 5. As for the same membrane-cushion interface friction angle, the maximum tensile force in the antiseepage membrane increased firstly and then decreased with the growth of the slope angle, and the inflection point showed when $\theta=39.5^{\circ}$. At the same slope angle, the ultimate tensile force in the antiseepage membrane went down with the rise of the friction angle of the membrane-cushion interface. The smaller the friction angle of the membrane-cushion interface, the lower the slope value $\theta$ when the tensile force was generated in the antiseepage membrane.

The change of tensile forces in the membrane at different depths is shown in Figure 6. The results show that for the same slope ratio, the smaller the friction angle of the

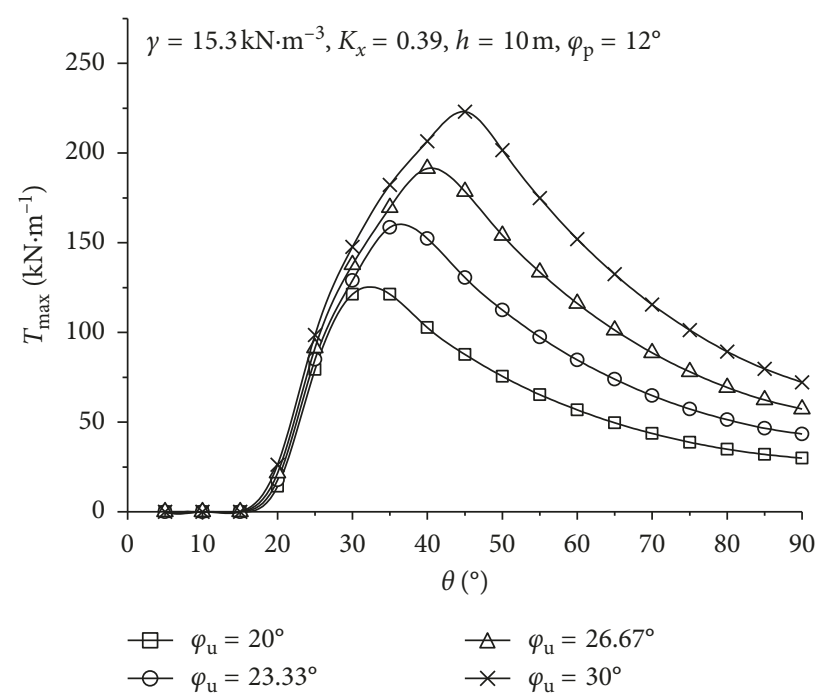

FIGURE 4: Changing of the ultimate tensile force in the membrane with the slope angle.

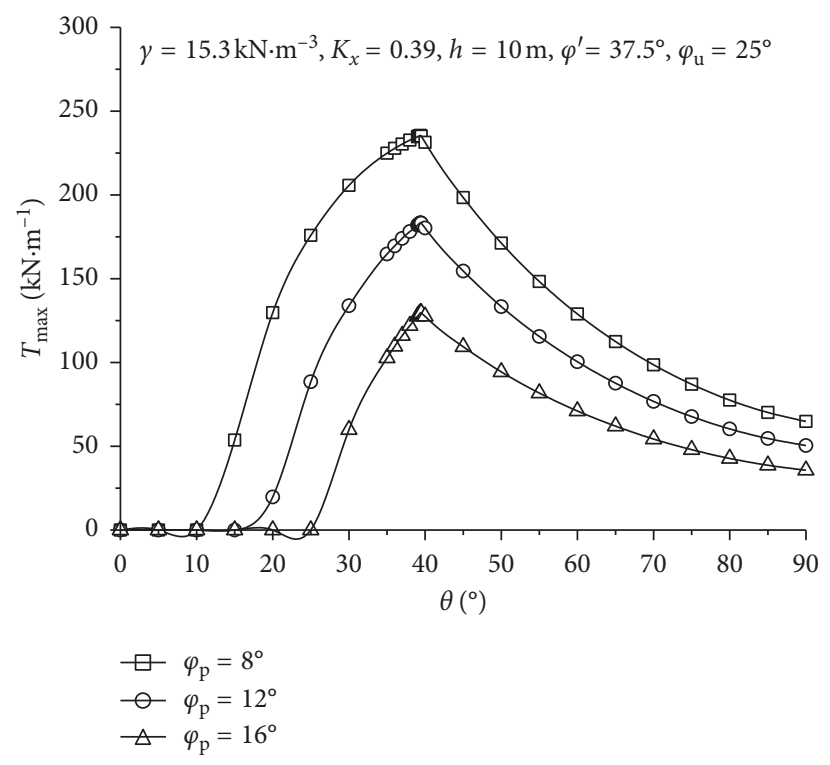

FIGURE 5: Change of the ultimate tensile force in the antiseepage membrane with the slope angle.

membrane-cushion interface, the faster the growth of the tensile force, and the greater the ultimate tensile force in the membrane. At the same buried depth, the lower the step height, the smaller the ultimate tensile force in the membrane.

As shown in Figure 7, the greater the buried depth, the larger the maximum tensile force at the anchored end of the antiseepage membrane, and the maximum tensile force on the antiseepage membrane was proportional to the buried depth. The pull-up force on the antiseepage membrane was the accumulation of the shear stress difference in the longitudinal direction, so the single-step height influenced the maximum tensile force on the antiseepage membrane greatly. 


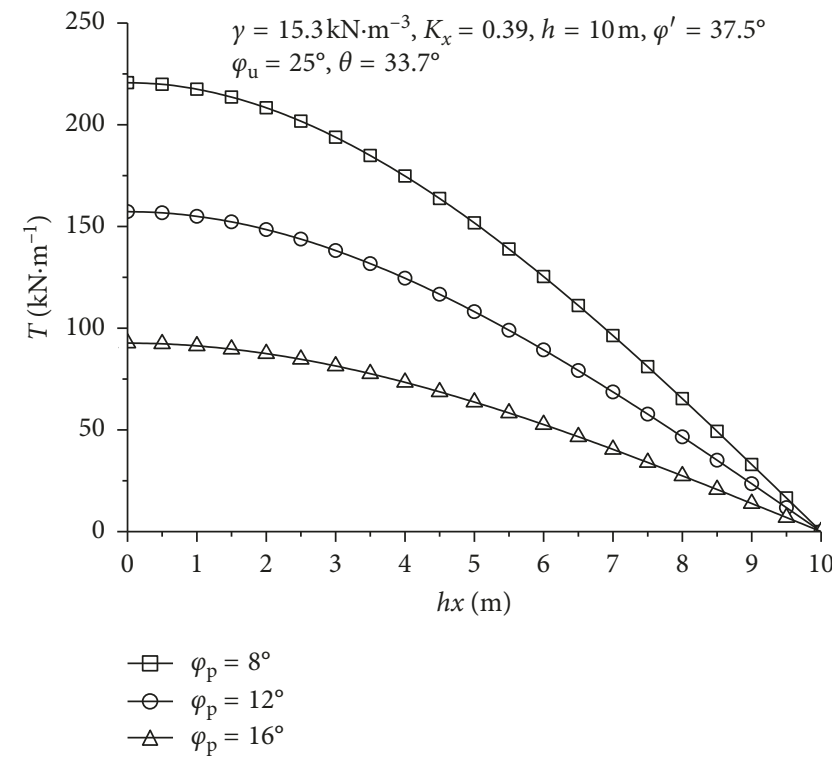

FIGURE 6: Change of the tensile force in the membrane at different depths.

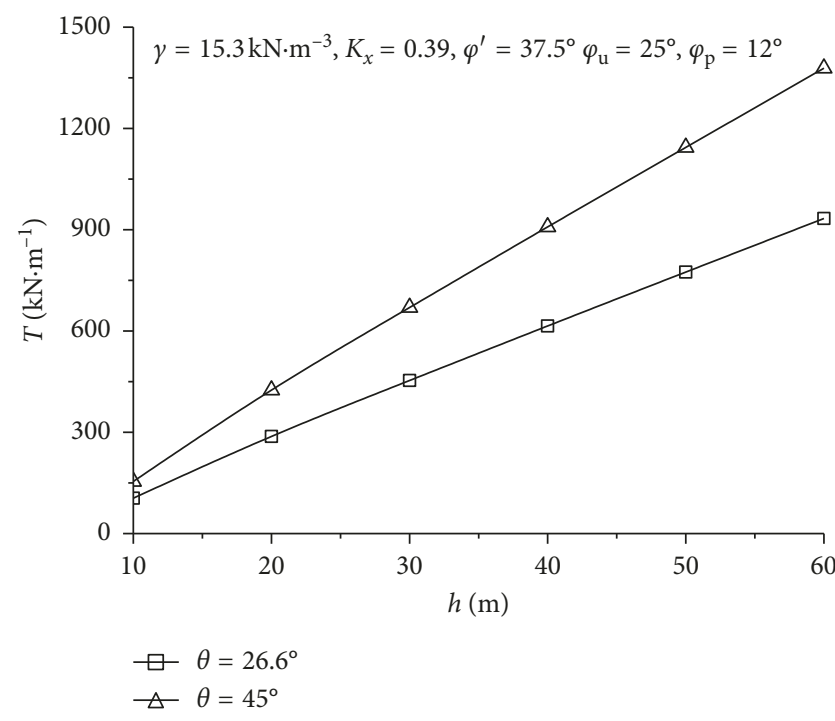

FIGURE 7: Relationship between the maximum tensile force at the anchored end and the buried depth.

\section{Numerical Investigation}

The investigation was based on the numerical simulation software FLAC2D and the single-interface modeling method. Considering the current applications of antiseepage membrane in most tailing ponds, the single step height designed for the mainstream antiseepage membrane laying was taken as the research object, and the numerical model was established when the slag accumulation height $h$ was $10 \mathrm{~m}$, in order to investigate the mechanical mechanism of the membraneslag interface at different slope ratios. The relevant parameters of the landfill body in the model were as follows: the average unit weight $\gamma=15.3 \mathrm{kN} / \mathrm{m}^{3}$, the elastic modulus $E=1 \times$ $10^{6} \mathrm{~Pa}$, Poisson's ratio $u=0.28$, and $\varphi_{\mathrm{u}}=25^{\circ}$.
4.1. Stress Comparative Analysis. In view of the mutual verification between the numerical and the theoretical models, a combination of theoretical analysis and numerical simulation was adopted in this paper. The numerical normal stress value, the theoretical normal stress value, and the normal stress on the slope resulted from the dead weight stress were compared (Figure 8). The theoretical and numerical solutions of the normal stress on the slope were close and showed the same growth trend. The numerical result was slightly lower than the theoretical value near the slope angle, generally affected by the slope angle boundary. The numerical solution of the normal stress on the slope is slightly smaller than its theoretical solution, lying between the theoretical solution and the calculation result of the tailings dead weight.

According to the normal stress distribution curve shown in Figure 9, at the same buried depth, the slope ratio had little effect on the interface normal stress, and the buried depth turned out to be the main factor influencing the normal stress. At the slope angle, the normal stress changed slightly due to the slope angle boundary.

As the distribution of membrane-slag interface shear stress in Figure 10 indicates, when the actual friction angle of the membrane-slag was smaller than the ultimate friction angle, the larger the slope angle, the greater the extreme value of the shear stress, the closer the extreme point to the bottom, and the greater the area between the shear stress curve of the membrane-slag interface and the horizontal axis. When the normal stresses were basically the identical, the shear stresses of the membrane-cushion interface were the same, which consequently led to larger tensile force in the membrane.

4.2. Tensile Force Comparative Analysis. Through numerical analysis, the maximum tensile forces in the membrane at different slope angles were compared with the theoretical values, as shown in Figure 11. The results showed that the trends of the ultimate tensile force in the membrane theoretically and numerically are basically the same. The maximum tensile force in the membrane increased with the rise of slope angle and then decreased after reaching its maximum value. At the same slope angle, the smaller the membrane-cushion friction angle, the greater the ultimate tensile force in the membrane. At the same slope angle and membrane-cushion friction angle, the numerical solution was slightly larger than the theoretical solution. Flac2d was based on the finite element model. Any part that shows motion relative to the lower cushion due to settlement or other factors will inevitably apply a pulling force on the upper grid, so that the membrane-slag interface at the upper part of the slope reaches the ultimate friction angle. The theoretical solution was based on the bulk material, regardless of the cohesive force. The sliding of the block object studied has no pull-down effect on the upper material along the slope, so the theoretical solution should actually be slightly smaller than the numerical solution. In addition, through the numerical model, when the slope is close to vertical, some interface nodes are separated due to the severe 


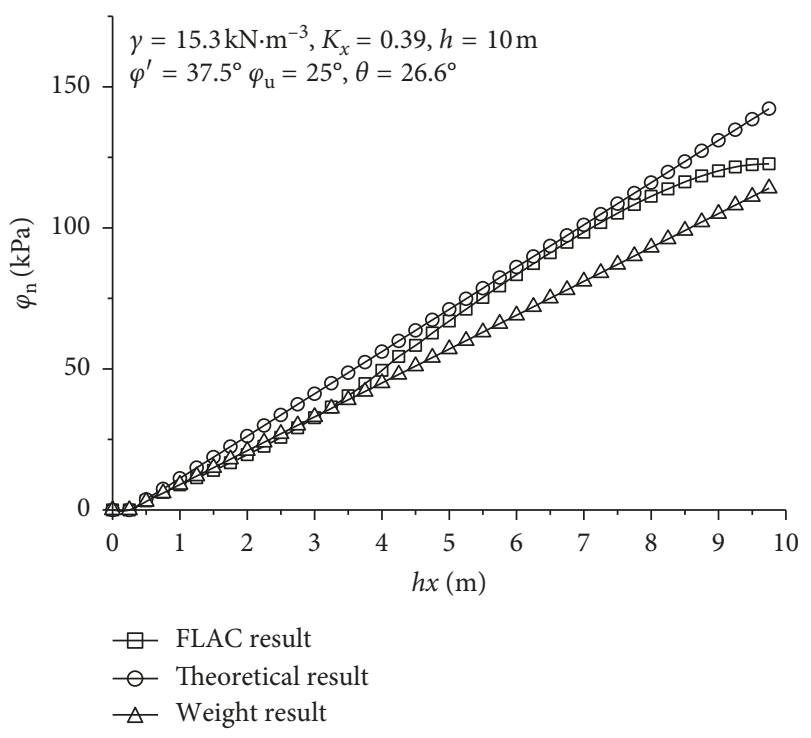

FIGURE 8: Interface normal stress distribution.

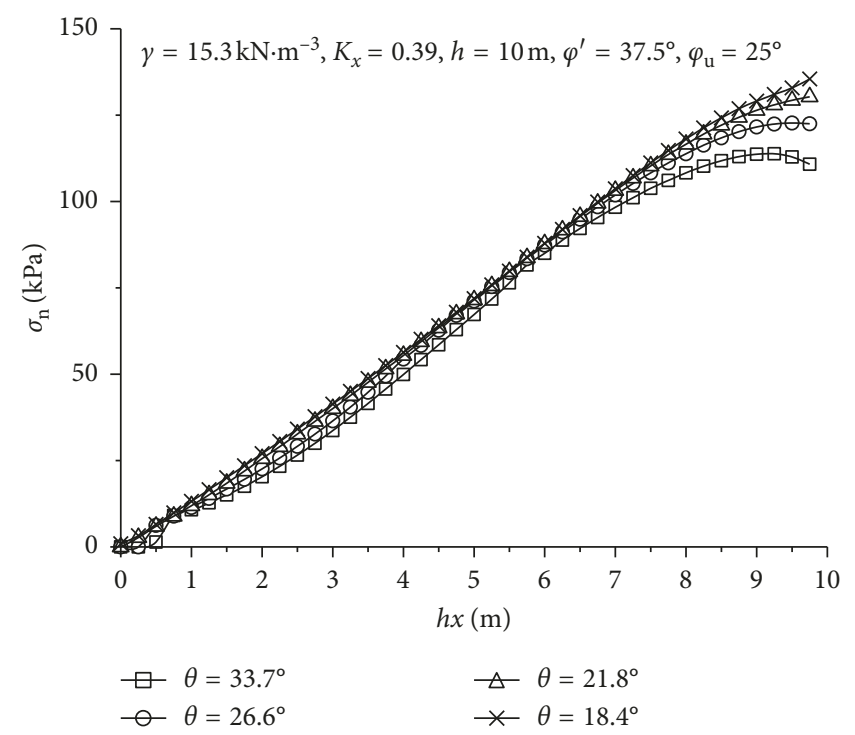

FIGURE 9: Interface normal stress distribution.

deformation of the numerical model, leading to 0 interface stress and a numerical solution lower than the theoretical solution. Therefore, the theoretical value is recommended when the slope angle is larger.

\section{Conclusion}

In the theoretical model, the effects of the landfill body dead weight, lateral pressure, settlement, and slope foundation were comprehensively considered. The differential equation of membrane-slag-cushion equilibrium was established, and the analytical solutions of the tensile force and displacement of the antiseepage membrane was calculated. The effects of related parameters were further studied through the combination of numerical and theoretical methods, with the results concluded as follows:

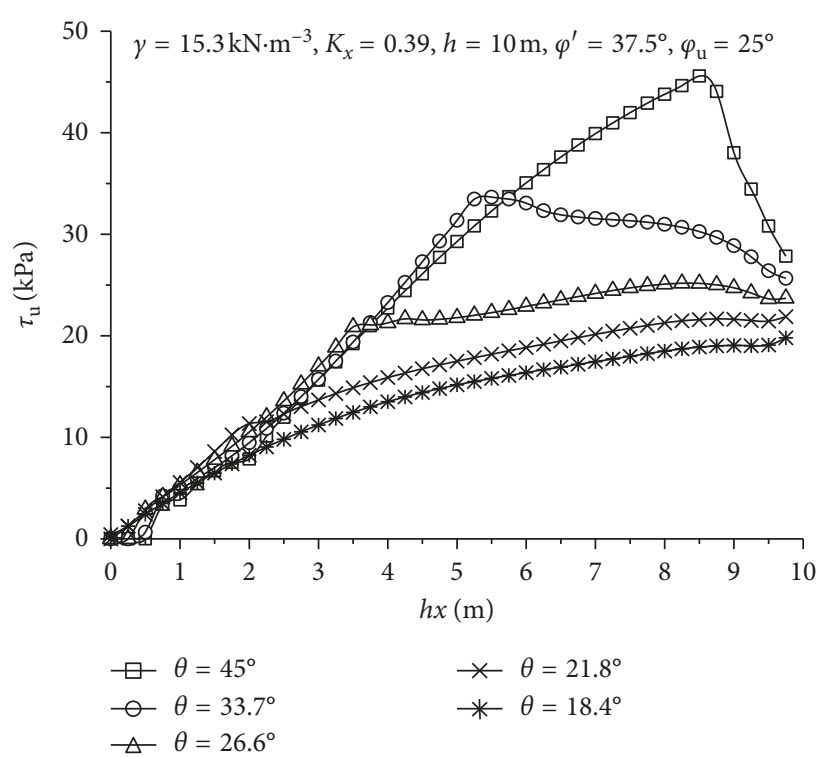

FIgURE 10: Distribution of membrane-slag interface shear stress.

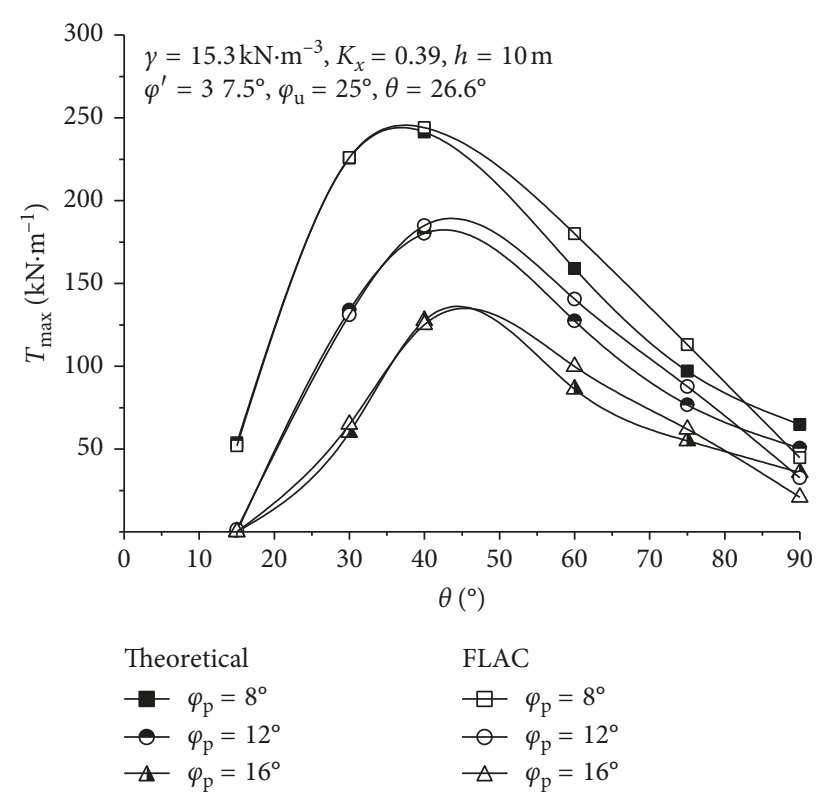

FIGURE 11: Change of ultimate tensile force in the membrane.

(1) The comparison of the theoretical and numerical tensile forces of the anchored end of the antiseepage membrane shows that the theoretical solution and the numerical solution reflect the same trend. The numerical value of the tensile force indicates that the hypothesis is quite in line with the practical reality, and the theoretical tensile force formula of the antiseepage membrane can be applied universally.

(2) The friction angles of the membrane-cushion interface and the membrane-slag interface are the major parameters affecting the tensile force of the membrane. Under the same conditions, the larger the friction angle of the membrane-cushion interface, the smaller the tensile force in the 
membrane; the smaller the friction angle of the membrane-slag interface, the smaller the tensile force in the membrane.

(3) The height of the landfill body on the antiseepage membrane and the height of the single step have a great influence on the internal tensile force of the antiseepage membrane. The height of the landfill body is proportional to the tensile force in the membrane. The higher the landfill, the greater the tensile force; the shorter the single step, the smaller the tensile force in the membrane.

(4) With the same landfill height, the ultimate tensile force of the antiseepage membrane on the slope at the ultimate slope angle reaches the maximum. On the slope which does not reach the ultimate slope angle, the ultimate tensile force in the antiseepage membrane goes up with the increase of the slope angle; on the slope which exceeds the ultimate slope angle, the ultimate tensile force in the antiseepage membrane goes down with the increase of the slope angle. Therefore, the landfill slope angle should be designed as far as possible from the ultimate slope angle in practices.

\section{Data Availability}

The data used to support the findings of this study are available from the corresponding author upon request.

\section{Conflicts of Interest}

The authors declare no conflicts of interest.

\section{Acknowledgments}

This work was supported by the Key Scientific Research Projects of Suzhou College (no. 2017yzd15). We sincerely acknowledge the former researchers for their excellent work, which greatly assisted our academic study.

\section{References}

[1] Y. J. Du, S. L. Shen, S. Y. Liu, and S. Hayashi, "Contaminant mitigating performance of Chinese standard municipal solid waste landfill liner systems," Geotextiles and Geomembranes, vol. 27, no. 3, pp. 232-239, 2009.

[2] X. Feng, N. Zhang, L. Gong, F. Xue, and X. Zheng, "Application of a backfilling method in coal mining to realise an ecologically sensitive "black gold" industry," Energies, vol. 8, no. 5, pp. 3628-3639, 2015.

[3] Z. Ma, R. Gu, Z. Huang, G. Peng, L. Zhang, and D. Ma, "Experimental study on creep behavior of saturated disaggregated sandstone," International Journal of Rock Mechanics and Mining Sciences, vol. 66, pp. 76-83, 2014.

[4] P. Gong, Z. Ma, X. Ni, and R. R. Zhang, "An experimental investigation on the mechanical properties of gangue concrete as a roadside support body material for backfilling gob-side entry retaining," Advances in Materials Science and Engineering, vol. 2018, Article ID 1326053, 11 pages, 2018.
[5] M. El-Fadel, A. N. Findikakis, and J. O. Leckie, "Environmental impacts of solid waste landfilling," Journal of Environmental Management, vol. 50, no. 1, pp. 1-25, 1997.

[6] J. X. Jiang, N. Liu, L. Wang, R. H. Peng, J. N. He, and Y. N. Gan, "Long distance with steep slope anti-seepage system reliability research under complicated load," Science Technology and Engineering, vol. 17, no. 25, pp. 115-119, 2017.

[7] J. X. Jiang and N. Liu, "Stability analysis of geomembrane in industrial tailings landfill slope," Journal of Central South University (Science and Technology), vol. 49, no. 3, pp. 672677, 2018.

[8] J. C. Zhou, "Application of HDPE geomembrane in municipal solid waste sanitary landfill site," Advances in Science and Technology of Water Resources, vol. 23, no. 3, pp. 53-56, 2003.

[9] R. K. Rowe, "Long-term performance of contaminant barrier systems," Géotechnique, vol. 55, no. 9, pp. 631-678, 2005.

[10] R. K. Rowe, R. M. Quigley, R. W. I. Brachman, and J. R. Booker, Barrier Systems for Waste Disposal Facilities, Taylor\&Francis Books Ltd. (E\&FN Spon), London, UK, 2004, ISBN 9780419226307.

[11] X. H. Chen and X. Q. Wang, "Migration of bentonite and influence upon performance of GCL," Journal of Yangtze River Scientific Research Institute, vol. 24, no. 4, pp. 53-56, 2007.

[12] C. Y. Xiao and F. Tu, "HDPE geomembrane-geotextile interface shear properties determined by large size direct shear test," Engineering Mechanics, vol. 27, no. 12, pp. 186-191, 2010.

[13] M. Barroso, N. Touze-Foltz, K. von Maubeuge, and P. Pierson, "Laboratory investigation of flow rate through composite liners consisting of a geomembrane, a GCL and a soil liner," Geotextiles and Geomembranes, vol. 24, no. 3, pp. 139-155, 2006.

[14] T. E. Martin and M. P. Davies, "Trends in the stewardship of tailings dams," in Tailings and Mine Waste’ 00, pp. 393-407, Balkema, Fort Colins, CO, USA, 2000, http://www.infomine. com/publications/docs/Martin2000.pdf.

[15] W. A. Lin, B. Zhu, and Y. M. Chen, "Tension analysis of geomembrane in landfill slope considering interface strainsoftening," Rock and Soil Mechanics, vol. 29, no. 8, pp. 2063-2069, 2008.

[16] P. zhang, J. H. Wang, and J. J. Chen, "Analysis of tension and displacement of geomembranes placed on landfill slopes," Rock and Soil Mechanics, vol. 25, no. 5, pp. 789-792, 2004.

[17] X. J. Deng, X. J. Kong, and D. G. Zhou, "Calculation of tension in HDPE geotechnical membrane under complicated loads," Chinese Journal of Geotechnical Engineering, vol. 29, no. 3, pp. 447-451, 2007.

[18] H. M. Wu and Y. M. Shu, "Stress-stain response of PVC geomembrane under uniaxial tension test," Advanced $M a$ terials Research, vol. 936, pp. 1582-1586, 2014.

[19] A. L. Welker and N. Josten, "Interfacefriction of a geomembrane with a fiber reinforced soil," in Proceedings of GeoFrontiers 2005 Congress, ASCE, pp. 2903-2910, Geotechnical Special Publication, Austin, TX, USA, January 2005.

[20] M. Chung, M. W. Seo, K. S. Kim, and J. B. Park, "Protective effect of overlying geosynthetic on geomembrane liner observed from landfill field tests and inclined board laboratory experiments," Waste Management and Research, vol. 24, no. 3, pp. 250-259, 2006.

[21] J. Kodikara, "Analysis of tension development in geomembranes placed on landfill slopes," Geotextiles and Geomembranes, vol. 18, no. 1, pp. 47-61, 2000. 
[22] J. P. Giroud and J. F. Beech, "Stability of soil layers on geosynthetic lining systems," in Proceedings of Geosynthetics'89 Conference, pp. 35-46, San Diego, CA, USA, February 1989.

[23] R. M. Koerner and B.-L. Hwu, "Stability and tension considerations regarding cover soils on geomembrane lined slopes," Geotextiles and Geomembranes, vol. 10, no. 4, pp. 335-355, 1991.

[24] C. N. Liu, "Tension of geosynthetic material regarding soils on landfill liner slopes," Proceedings of the National Science Council, Re ic of China Part A, Physical Science and Engineering, vol. 25, no. 4, pp. 211-218, 2001.

[25] C. N. Liu and R. B. Gilbert, "Simplified method for estimating geosynthetic loads in landfill liner side slopes during filling," Geosynthetics International, vol. 10, no. 1, pp. 24-33, 2003.

[26] C. N. Liu and R. B. Gilbert, "Graphical solution for estimating geosynthetic load in geosynthetic-soil layered systems on slopes," Geosynthetics International, vol. 12, no. 4, pp. 208214, 2005.

[27] M. W. See, J. B. Park, I. J. Park, and M. K. Chung, "Modeling of interface shear behavior between Geosynthetics," KSCE Journal of Civil Engineering, vol. 7, no. 1, pp. 9-13, 2003. 


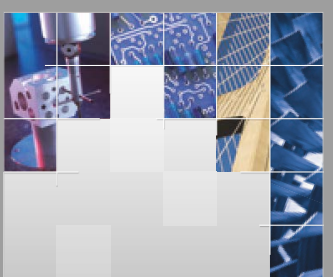

\section{Enfincering}
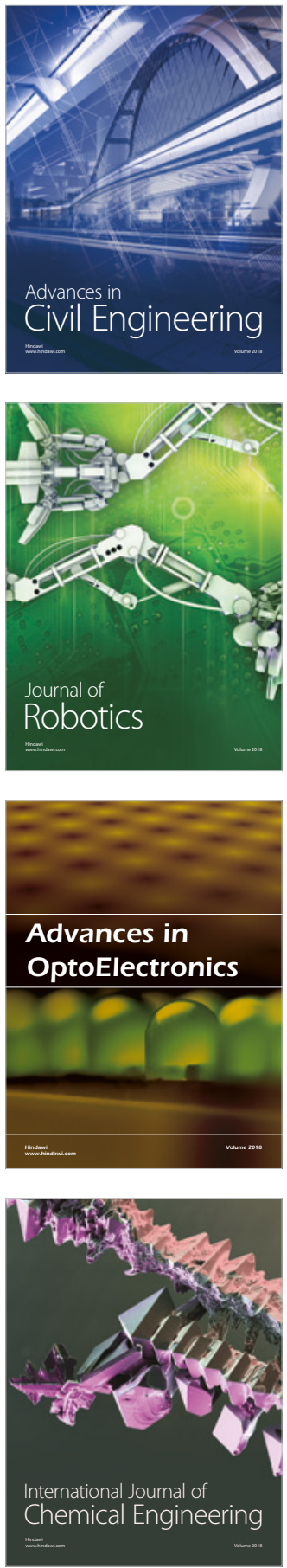

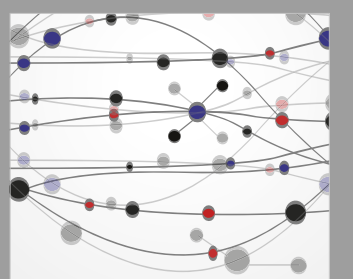

\section{Rotating \\ Machinery}

The Scientific World Journal

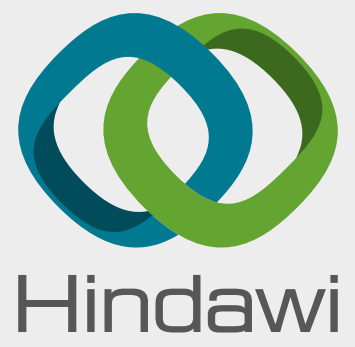

Submit your manuscripts at

www.hindawi.com
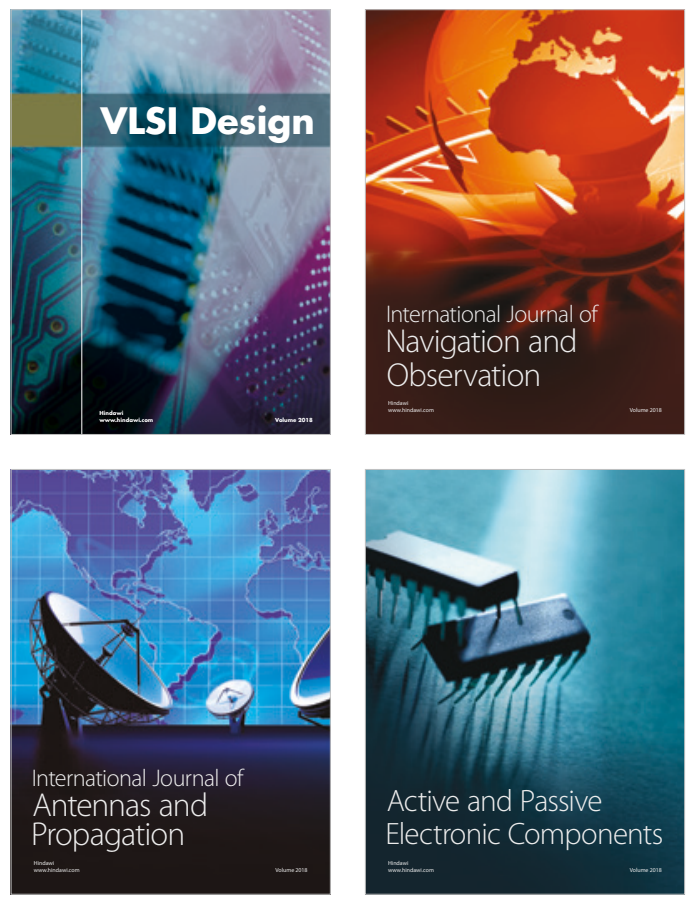
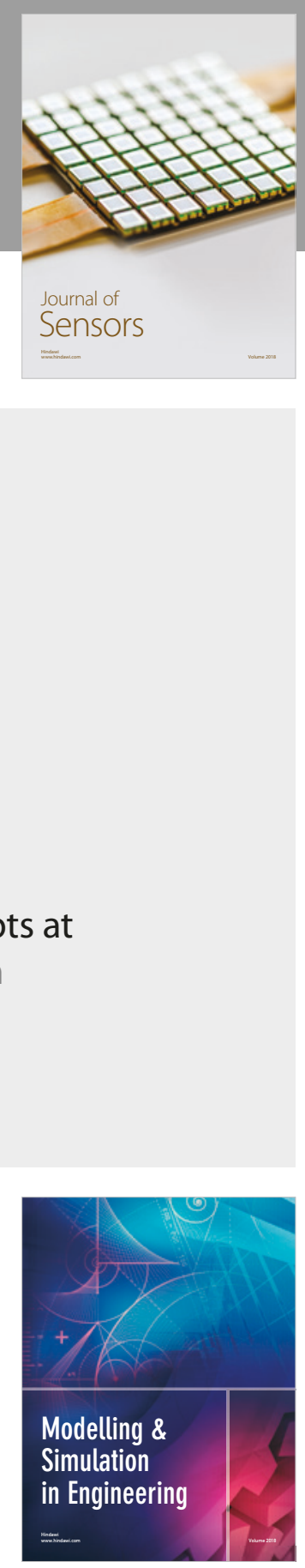

\section{Advances \\ Multimedia}
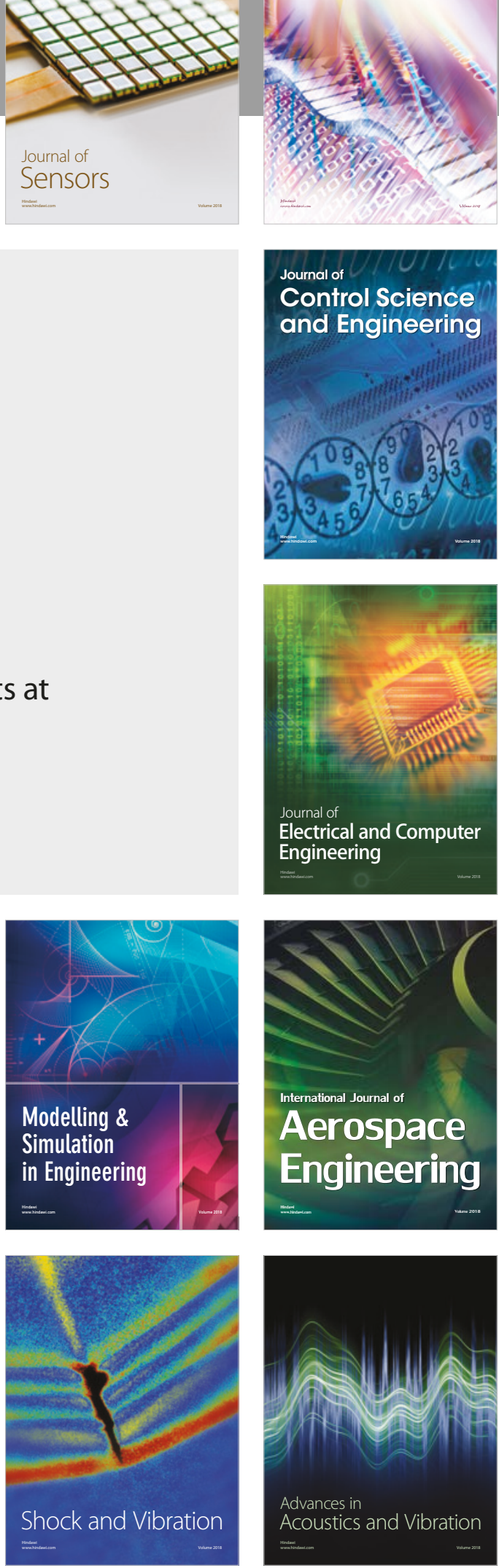